\title{
AS PARCERIAS PÚBLICO-PRIVADAS (PPPS) E A CONSTITUIÇÃO
}

\author{
GUSTAVO BINENBOJM*
}

Nota Prévia - I. A formatação jurídica e a lógica econômica das novas modalidades de contratação pública introduzidas pela Lei $n^{\circ}$ 11.079/2004. - I.1. A concessão patrocinada. - I.2. A concessão administrativa. - Il. A questão da constitucionalidade dos modelos contratuais propostos na Lei $n^{\circ} 11.079 / 2004$. - III. Aplicabilidade da Lei $n^{\circ} 11.079 / 2004$ a Estados, Distrito Federal e Municípios: a questão das normas gerais. - IV. As garantias especiais das PPPs: exigência de lei complementar e problemas relativos ao fundo garantidor. $-V$. A arbitragem envolvendo a Administração Pública. .

\section{Nota Prévia}

O propósito do presente estudo é o de analisar as inovações mais importantes introduzidas no ordenamento jurídico brasileiro pela Lei $n^{\circ} 11.079$, de 30 de dezembro de 2004 - a chamada "Lei das Parcerias Público-Privadas (PPPs)" - à luz dos princípios e regras da Constituição da República.

$O$ alcance de tal desiderato pressupõe, todavia, um exame, ainda que perfunctório, da formatação jurídica dessas novas modalidades de contratação pública denominadas PPPs, bem como da lógica econômica a elas subjacente, que lhes confere uma tônica peculiar e lhes serve de justificativa política.

- Professor de Direito Administrativo da Faculdade de Direito da Universidade do Estado do Rio de Janeiro - UERJ; Professor do Curso de Pós-Graduação da Fundaçăo Getúlio Vargas - FGV; Professor da Escola da Magistratura do Estado do Rio de Janeiro - EMERJ; Master of Laws. Yale Law School; Mestre e Doutorando em Direito Público pela Faculdade de Direito da UERJ; Procurador do Estado, advogado e parecerista no Rio de Janeiro. 


\section{A formatação jurídica e a lógica econômica das novas modalidades de contratação pública introduzidas pela Lei $n^{\circ} 11.079 / 2004$.}

Sob o rótulo de parcerias público-privadas (PPPs), a Lei $\mathrm{n}^{\circ} 11.079$, de $30 \mathrm{de}$ dezembro de 2004, introduziu no Brasil duas novas modalidades de contratação pública: as concessões patrocinadas e as concessões administrativas. A tais espécies contratuais, e só a elas, o ordenamento jurídico brasileiro reservou o emprego do badalado nomen iuris.

Na verdade, até a edição da Lei $\mathrm{n}^{\circ} 11.079 / 2004$, a expressão PPP vinha sendo empregada entre nós em sentido mais amplo - e, por vezes, equívoco - mercê de influências estrangeiras as mais variegadas, para designar os múltiplos vínculos negociais, de trato continuado, estabelecidos entre a Administração Pública e particulares, com vistas ao desenvolvimento, por estes últimos, de atividades econômicas ou sociais com algum coeficiente de interesse coletivo'. Assim, designaram-se como PPPs desde as concessões e permissões de serviços públicos (regidas pela Lei $\mathrm{n}^{0}$ $8.987 / 95$ e por leis específicas e setoriais, agora rebatizadas como concessões comuns), aplicáveis aos serviços de cunho econômico, até os mais recentes contratos de gestão com organizações sociais (regidos pela Lei $\mathrm{n}^{\circ}$ 9.637/98) e termos de parceria com organizações da sociedade civil de interesse público (regidos pela Lei $n^{\circ}$ 9.790/99), aplicáveis aos serviços de natureza social.

Com a edição da Lei $n^{\circ} 11.079 / 2004$, todavia, PPP, no direito brasileiro, passa a designar contratos administrativos de um tipo específico, aos quais corresponderá um igualmente específico regime jurídico.

\section{I.1. A concessão patrocinada.}

A concessão patrocinada é espécie do gênero concessão de serviço público (ou concessão de serviço público precedida de obra pública, ou apenas concessão de obra pública), em que a remuneração do concessionário envolve, adicionalmente à tarifa cobrada dos usuários, uma contraprestação pecuniária devida pelo poder concedente (art. $2^{\circ}, \S 1^{\circ}$, da Lei $n^{\circ} 11.079 / 2004$ ). A distinção fundamental, portanto, entre a nova concessão administrativa e a concessão comum (regida pela Lei $\mathrm{n}^{\circ}$ 8.987/95) está na forma de remuneração do concessionário: na primeira, o Poder Público comparece com pagamentos de natureza pecuniária, complementares à tarifa; na segunda, além da cobrança da tarifa, pode o concessionário ser remunerado por receitas alternativas (Lei $n^{\circ} 8.987 / 95$ ), desde que estas não envolvam pagamentos de natureza pecuniária feitos pela Administração Pública ${ }^{2}$.

1 Carlos Ari Sundfeld, Guia Jurídico das Parcerias Público-Privadas, in Parcerias Público-Privadas, Editora Malheiros, 2005, p. 22.

2 Segundo Carlos Ari Sundfeld, a concessão comum não se desnatura se a remuneração do concessionário incluir (ou limitar-se à) contraprestação não-pecuniária feitas pela Administração, nas modalidades previstas no art. $6^{\circ}$, III (outorga de direitos em face da Administração) e IV (outorga de direitos sobre bens públicos dominicais), da Lei $n^{\circ} 11.079 / 2004$. Op. cit., p. 27. 
Uma outra distinção importante entre as concessões comuns e as patrocinadas diz respeito à distribuição dos riscos dos empreendimentos. Enquanto na modalidade comum o art. $2^{\circ}$, incisos II. III e IV, da Lei $\mathrm{n}^{\circ} 8.987 / 95$ prevê enfaticamente a assunção da execução da obra ou serviço pelo concessionário por sua conta e risco, o art. $4^{\circ}$, inciso VI, da Lei ${ }^{\circ} 11.079 / 2004$ estabelece, como uma das diretrizes das PPPs, a repartição objetiva de riscos entre as partes. Embora a Lei $\mathrm{n}^{\circ} 11.079 / 2004$ não disponha, ela mesma, sobre como serão compartilhados os riscos, tal matéria deverá constar obrigatoriamente do contrato de PPP (art. $5^{\circ}$, III).

É interessante notar que a idéia da concessão patrocinada estava contida no art. 24 do projeto de lei aprovado pelo Congresso Nacional e que viria a se converter na Lei $n^{\circ} 8.987 / 95$. Não fosse pelo veto do então Presidente Fernando Henrique Cardoso, a idéia da concessão patrocinada ter-se-ia introduzido no país há quase dez anos. Confira-se, a propósito, o teor do aludido dispositivo:

"Art. 24. O poder concedente poderá garantir, no contrato de concessão, uma receita bruta mínima ou, no caso de obras viárias, o correspondente a um tráfego mínimo, durante o primeiro terço do prazo da concessão."

À época, nas razões de veto do Presidente, foi dito que "garantias como essa do estabelecimento de receita bruta mínima, além de incentivarem ineficiência operacional do concessionário, representam, na realidade, um risco potencial de dispêndio com subsídio pelo Poder Público" " ${ }^{3}$ Embora a Lei $n^{\circ} 11.079 / 2004$ não se tenha referido literalmente a "receitas mínimas brutas", distorções na modelagem dos contratos podem levar à configuração de um tal quadro. Este, dentre outros, é um dos riscos criados pelo instrumento da concessão patrocinada, que envolvem ainda a possibilidade de uso populista do patrocínio para garantir tarifas excessivamente baixas e o comprometimento da responsabilidade fiscal no médio e longo prazos.

Mas, se assim é, o que justifica este ingresso tardio das concessões patrocinadas no ordenamento jurídico brasileiro? Qual a sua lógica econômica?

As justificativas econômicas para a institucionalização das PPPs, em sua modalidade de concessão patrocinada, a despeito dos riscos a ela inerentes, são as seguintes:

(I) o esgotamento da capacidade de endividamento do Estado, em um ambiente político que valoriza a responsabilidade fiscal e o régio cumprimento das obrigações assumidas pelo governo brasileiro com seus credores nacionais e internacionais. Tal circunstância reduz significativamente a capacidade de investimento do Poder Público em infra-estrutura e serviços públicos, gerando os conhecidos "gargalos" estruturais e aumentando o chamado custo Brasil. Daí a enorme demanda por inves-

3 O caso mais recente de uso abusivo dos subsídios foi o mecanismo instituído pela Lei $n^{\circ}$ $5.655 / 71$, que criou a Conta de Resultados a Compensar (CRC), extinta, em 18.3.93, com a regulamentação da Lei $\mathrm{n}^{\circ} 8.631 / 93$, gerando dispêndios líquidos para a União da ordem de US\$ 19,8 bilhões. 
timentos privados para o financiamento desses setores, o que, todavia, pressupõe a criação de condições favoráveis por parte do Poder Público;

(II) exaurimento progressivo dos serviços públicos econômicos auto-sustentáveis, o que inviabiliza a opção pelo formato da concessão comum. Rodovias cuja receita com pedágio não cubra os custos de operação e manutenção (ou o investimento inicial na construção, recuperação ou ampliação da infra-estrutura), embora não sejam rentáveis para a iniciativa privada, podem vir a proporcionar um retorno econômico e social extremamente positivo. ${ }^{4}$ Daí ser justificável a previsão de uma contraprestação pecuniária do parceiro público ao privado, como forma de criar o ambiente de atratividade necessário para seduzir os investidores particulares.

\subsection{A concessão administrativa.}

A concessão administrativa é o contrato de prestação de serviços de que a Administração Pública seja a usuária direta ou indireta, ainda que envolva a execução de obra ou o fornecimento e instalação de bens (art. $2^{\circ}, \S 2^{\circ}$, da Lei $n^{\circ} 11.079 / 2004$ ). Servem ainda para delimitar os contornos dessa modalidade contratual as vedações constantes do $\S 4^{\circ}$ do art. $2^{\circ} \mathrm{c} / \mathrm{c}$ art. $5^{\circ}$, I, a saber: (i) o investimento feito pelo particular não pode ser inferior a $R \$ 20.000 .000,00$ (vinte milhões de reais); (ii) o periodo de prestação do serviço não pode ser inferior a 5 (cinco) anos nem superior a 35 (trinta e cinco) anos; (iii) o contrato não pode ter como objeto único o fornecimento de mão-de-obra, o fornecimento ou instalação de equipamentos ou a execução de obra-pública.

A referência à Administração Pública como usuária direta ou indireta dos serviços dá margem a que se concebam duas subespécies de concessão administrativas:

(a) a concessão administrativa de serviço público, espécie do gênero concessão de serviço público, sendo este prestado diretamente ao usuário, sem cobrança de qualquer tarifa, e sendo o concessionário remunerado por contraprestação pecuniária do Poder Público (em conjunto ou não com outras receitas alternativas). Em tal hipótese, a Administração Pública é de ser considerada a usuária indireta dos serviços, vez que estes são prestados diretamente pela concessionária à população. Este seria o caso, por exemplo, de um serviço de coleta de lixo, sem cobrança de tarifa dos usuários diretos;

(b) a concessão administrativa de serviços ao Estado, espécie do gênero contrato de prestação de serviços, mediante o qual utilidades são oferecidas à própria Admi-

4 Assim, na feliz síntese de Marcos Barbosa Pinto, os projetos de PPPs, na modalidade de concessão patrocinada, são aqueles que exibem grandes externalidades positivas. No caso da rodovia de baixa rentabilidade, a externalidade positiva consiste no montante em que o benefício social maiginal supera o benefício privado marginal do empreendimento. V. A Função Económica das PPPs, mimeo., gentilmente cedido pelo autor, p. 5.

5 Adota-se aqui a classificação proposta por Carlos Ari Sundfeld em Guia Juridico das Parcerias Público-Privadas, in Parcerias Público-Privadas, Editora Malheiros, 2005, p. $29 / 30$. 
nistração Pública, sua usuária direta. Aqui, diferentemente, todavia, de um contrato comum de prestação de serviços, exige-se do particular um investimento inicial igual ou superior a R\$ $20.000 .000,00$ (vinte milhões de reais) em obra ou equipamento que sejam essenciais à futura prestação dos serviços.

A lógica econômica da concessão administrativa de serviço público assemelhase à da concessão patrocinada, por envolver serviços econômicos não auto-sustentáveis. A diferença é que nesta modalidade, por razões técnicas, políticas ou econômicas, não se afigura viável a cobrança de qualquer tarifa dos usuários diretos, 0 que justifica que a contraprestação do concessionário fique a cargo do Poder Público, total ou parcialmente (caso haja receitas alternativas suscetíveis de serem geradas).

A lógica econômica da concessão administrativa de serviços ao Estado prende-se não apenas ao esgotamento da capacidade de endividamento e investimento do Estado, mas também à busca por um aumento do grau de eficiência na gestão de obras e serviços públicos e no dispêndio de recursos oficiais. $O$ prazo mais dilargado (entre 5 e 35 anos) é justificado pela necessidade de amortização diferida do investimento feito pelo parceiro privado, na medida em que os serviços forem sendo prestados. Com efeito, só prazos mais longos na prestação de serviços podem tornar atrativos os investimentos vultosos exigidos do particular. De outro lado, a maior flexibilidade na elaboração do projeto (projeto básico e projeto executivo), a transferência de parte dos riscos do empreendimento e a variabilidade da remuneração conforme os resultados alcançados criam incentivos para a execução das tarefas, com maior eficiência gerencial, pelos parceiros privados.

O grave risco ensejado pelas concessð̃es administrativas de serviços ao Estado é o do seu uso com desvio de finalidade. De fato, é possível - ou mesmo previsível - que administradores públicos descompromissados com a moralidade administrativa venham a pretender usar a disciplina jurídica da Lei das PPPs, na modalidade de concessão administrativa de serviços ao Estado, para as mesmas situações em que seria exclusivamente aplicável a disciplina dos contratos administrativos da Lei de Licitações (Lei $n^{\circ}$ 8.666/93). É de todo inconcebível que simples contratos de vigilância, de limpeza, de manutenção de equipamentos, ou outros que tais, possam ter prazos de vigência de até 35 (trinta e cinco) anos, sem que qualquer investimento inicial de vulto o justifique ${ }^{6}$.

Assim, além da nota da complexidade (combinação de obras, fornecimento de bens ou equipamentos e prestação de serviços), é mister que se exija necessariamente o investimento inicial do parceiro privado na criação, ampliação ou recuperação de alguma infra-estrutura (obras e/ou equipamentos), no montante mínimo estabelecido em lei, como justificativa jurídica a constar da fase interna de licitação para a contratação de PPP, na modalidade de concessão administrativa de serviços ao Estado. Aqui, como nas concessões patrocinadas, o uso da PPP deve ser excepcional e especificamente motivado, como o tipo de contratação que melhor atende ao

6 Nesses casos, aplicam-se os prazos máximos de um ano, prorrogáveis até o limite de cinco anos, conforme previsto no art. 57, caput, II, da Lei $n^{\circ} 8.666 / 93$. 
interesse público, consideradas as circunstâncias do caso concreto (Lei $n^{\circ}$ 11.079/2004, art. 10, I, “a”)

Feita essa breve apresentação dos contornos jurídicos dos contratos de PPP, e da lógica econômica sobre a qual estão erigidos, passa-se, a seguir, ao exame das principais controvérsias constitucionais suscitadas pelo novel instituto.

II. A questão da constitucionalidade dos modelos contratuais propostos na Lei $n^{\circ}$ $11.079 / 2004$.

Em três dispositivos específicos, a Constituição brasileira faz alusão às contratações públicas como instrumentos de que pode se valer o Poder Público para a execução de suas tarefas. Veja-se:

"Art. 22. Compete privativamente à União legislar sobre:

XXVII - normas gerais de licitação e contratação, em todas as modalidades, para as administrações públicas diretas, autárquicas e fundacionais da União, Estados, Distrito Federal e Municipios, obedecido o disposto no art. 37, XXI, e para as empresas públicas e sociedades de economia mista, nos termos do art. $173, \S 1^{\circ}$, III."

"Art. 37.

$X X I$ - ressalvados os casos especificados na legislação, as obras, serviços, compras e alienações serão contratados mediante processo de licitação pública que assegure igualdade de condições a todos os concorrentes, com cláusulas que estabeleçam obrigações de pagamento, mantidas as condições efetivas da proposta, nos termos da lei, o qual somente permitirá as exigências de qualificação técnica e econômica indispensáveis à garantia do cumprimento das obrigações."

"Art. 175. Incumbe ao Poder Público, na forma da lei, diretamente ou sob regime de concessão ou permissão, sempre através de licitação, a prestação de serviços públicos.

Parágrafo único. A lei disporá sobre:

$I$ - o regime das empresas concessionárias e permissionárias de serviços públicos, o caráter especial de seu contrato e de sua prorrogação, bem como as condições de caducidade, fiscalização e rescisão da concessão ou

7 “Art. 10. A contratação de parceria público-privada será precedida de licitação na modalidade de concorrência, estando a abertura do processo licitatório condicionada a: I — autorização da autoridade competente, fundamentada em estudo técnico que demonstre: a) a conveniência e a oportunidade da contratação, mediante identificação das razões que justifiquem a opção pela forma de parceria público-privada." 


\section{permissão;}

II - os direitos dos usuários;

III - política tarifária;

IV - a obrigação de manter serviço adequado."

Como se vê, e não há grande novidade em dizê-lo, a Constituição brasileira não adota um regime de tipicidade fechada em relação às modalidades contratuais que podem vir a ser instituídas e utilizadas pelo Poder Público para a melhor execução de suas tarefas. Assim, obedecidas as balizas traçadas pelo constituinte, a formatação jurídica dos contratos da Administração é matéria sujeita à livre conformação do legislador - tanto do federal, no que toca à definição de normas gerais, quanto o dos Estados, Distrito Federal e Municípios, naquilo que diga respeito às peculiaridades regionais e locais.

Assim sendo, e - repita-se - observados os limites cravejados na própria Lei Maior, compete ao legislador instituir os mecanismos jurídicos que viabilizem as escolhas mais eficientes para o administrador público, conforme as circunstâncias em que inserido, na sua tarefa de prestação de utilidades à população.

A Lei $n^{\circ} 11.079 / 2004$ é apenas mais uma lei geral (ou lei-quadro) sobre contratação pública (aludida no art. 22, XXVII, CF), que vem se somar às Leis $\mathrm{n}^{\circ}$ 8.666/93 e 8.987/95 (além das demais leis setoriais) ao fito de proporcionar à Administração Pública os meios jurídicos para desenvolver, da forma mais eficiente possível, a prestação de serviços públicos. Em um contexto de contingenciamento brutal de investimentos públicos e de exaurimento progressivo dos serviços públicos econômicos ditos auto-sustentáveis, a Lei $n^{\circ} 11.079 / 2004$ parece oferecer aos gestores públicos brasileiros mecanismos criativos e inovadores para o financiamento, a execução e a gestão de obras, equipamentos e operação de serviços públicos.

Por evidente, diante do comprometimento contratual de recursos públicos no longo prazo com determinados projetos, foi essencial a exigência constante do art. 10, I, "a", da Lei n' 11.079/2004, de que qualquer contratação de PPP esteja lastreada em estudo técnico que demonstre a conveniência e oportunidade da contratação, mediante identificação das razões que justifiquem a opção pela forma de parceria público-privada. Dado o caráter excepcional da PPP, em tal estudo deverá ser demonstrado que a opção por tal forma de contratação é aquela que, comparativamente às demais existentes, é a que melhor (ou mesmo a única) capaz de alavancar os investimentos necessários ao desenvolvimento de determinado projeto, propiciando, ainda, a mais otimizada maneira de dispêndio dos recursos públicos envolvidos vis-à-vis do grau de benefício econômico e social trazido para a população. Assim concebido, o contrato de PPP me parece ser uma solução legislativa que permite o alcance, conforme as circunstâncias do caso concreto, de um maior grau de concretização do princípio da eficiência administrativa (CF, art. 37, caput).

No que se refere às espécies de PPP contempladas na Lei ${ }^{\circ} 11.079 / 2004$ (a concessão patrocinada e a concessão administrativa), há ainda algumas controvérsias a serem dirimidas.

Primeiro: nada - absolutamente nada - no texto e no espírito do art. $175 \mathrm{da}$ Carta da República pressupõe ou dá a entender que, nas concessões de serviços 
públicos, a atividade do concessionário (isto é, a prestação dos serviços à população) tenha de ser suportada exclusivamente pelo pagamento de tarifa pelos usuários. Com efeito, o que está previsto no parágrafo único e seus incisos do mencionado preceptivo constitucional é que a lei disporá sobre o regime jurídico das empresas concessionárias, o caráter especial de seu contrato e sobre política tarifária. Ora, dispor sobre política tarifária não significa exigir que a tarifa seja o único mecanismo de remuneração do concessionário. Bem ao revés, o pagamento de tarifa pode vir a ser uma dessas formas de remuneração, combinada ou substituída por outras, como, por exemplo:

(I) as receitas alternativas (Lei $n^{\circ} 8.987 / 95$, art. 11), em complementação ou substituição da receita tarifária. A hipótese é aqui de concessão comum, não qualificada como PPP;

(II) as contraprestações pecuniárias pagas pelo Poder Público em complementação (Lei $n^{\circ} 11.079 / 2004$, art. $2^{\circ}, \S 1^{\circ}$ ) ou substituição da receita tarifária (Lei $n^{\circ} 11.079 / 2004$, art. $2^{\circ}, \S 2^{\circ}$ ). A primeira hipótese é de PPP, na modalidade de concessão patrocinada, enquanto a segunda é de PPP, na modalidade de concessão administrativa de serviços püblicos (o Poder Público é o usuário indireto);

(III) as contraprestações não-pecuniárias pagas pelo Poder Público em complementação ou substituição da receita tarifária (Lei n 11.079/2004, art. $6^{\circ}$, III e IV c/c Lei n 8.987/95, art. 11). A hipótese, aqui, é de concessão comum, não qualificada como PPP.

O que caracteriza o contrato administrativo de concessão de serviços públicos não é o pagamento da tarifa (ou de tarifa cheia) pelos usuários, mas a circunstância da sua gestão, execução e prestação direta do serviço pelo concessionário ao usuário. Uma política tarifária com tarifa zero pode ser a única ou a que melhor realiza o interesse público em um determinado caso. Em outros casos, a tarifa poderá ser subsidiada ou complementada, como forma de assegurar o acesso ao serviço pela população de baixa renda ou como meio de garantir a sustentabilidade econômicofinanceira do negócio assumido pclo parceiro privado. Em suma: fazer política tarifária, nos termos e para os fins do art. 175, parágrafo único, inciso III, da Constituição, significa dispor sobre se, quando e em que circunstâncias e proporção a remuneração do concessionário deve ser suportada por usuários, Poder Público ou por outras receitas alternativas decorrentes ou associadas à prestação dos serviços à população.

Segundo: o que dizer das concessöes administrativas de serviços ao Estado? Por certo estas não se configuram como contratos de concessão de serviços públicos, mas como verdadeiros contratos de prestação de serviços ao Poder Público, combinados com prévia execução de obra pública ou prévio (ou concomitante) fornecimento (ou instalação) de equipamentos. 
Merece destaque a posição de Paulo Modesto no sentido de que, de ordinário, "a concessão administrativa deve ser qualificada como um contrato administrativo misto, híbrido, envolvendo um contrato de prestação de serviços e uma concessão de uso ou de obra pública, nomeadamente quando envolver a utilização de instalações privativas do Poder Público ou a execução de

obra ou fornecimento de bens." 8 Todavia, como o próprio autor reconhece, nem sempre haverá concessão de obra ou de uso de bem público, ficando tal definição na dependência da escolha feita na modelagem do edital.

Pois bem. Como já dito acima, não há qualquer óbice constitucional a que o legislador combine diferentes objetos e formas de execução em um único contrato administrativo, com vistas a permitir o adequado equacionamento de situações que não poderiam ser acudidas, com idêntico grau de eficiência, pelas vias contratuais tradicionais.

É claro que a demonstração da vantagem sócio-econômica trazida pela PPP é também imprescindível para concessões administrativas de serviços ao Estado, como condição imposta pelos princípios constitucionais da moralidade e da eficiência (CF, art. 37, caput). Do contrário ter-se-á fraude à lei, caracterizada pelo desvio na utilização do regime da Lei $n^{\circ} 11.079 / 2004 \mathrm{em}$ situações que deveriam ser encaminhadas segundo o regime da Lei $n^{\circ} 8.666 / 93$. Mas esse risco de abuso per se não tem o condão de carrear para a Lei $n^{\circ} 11.079 / 2004$ a pecha de inconstitucional.

Terceiro: o compartilhamento de riscos entre os parceiros público e privado, contemplado no art. $4^{\circ}$, VI e no art. $5^{\circ}$, III, da Lei ${ }^{\circ} 11.079 / 2004$, importaria violação ao princípio da manutenção do equilíbrio econômico-financeiro dos contratos administrativos, especialmente do art. $37, \mathrm{XXI}$, que assegura a manutenção das "condiçð̃es efetivas da proposta"?

A resposta me parece ser um rotundo não. Estando prevista a repartição objetiva dos riscos na lei de regência e vindo tal repartição a ser claramente explicitada no edital, não há que se falar em quebra de equilíbrio econômico-financeiro, muito menos em desvirtuamento das condições efetivas da proposta. Como bem esclarece Marcos Barbosa Pinto, "quando o próprio contrato (rectius: o edital da licitação) prevê ex ante que certos riscos serão arcados pelo parceiro privado, os licitantes têm a oportunidade de precificar esses riscos em sua proposta. Portanto, ainda quando o administrador público erre a mão e transfira mais riscos do que seria recomendável na PPP, o particular não sofre prejuízo, pois o risco ineficientemente transferido já foi levado em conta na formulação da proposta." 9

Assim, caberá ao administrador público a busca, em cada caso, pela mais eficiente forma de alocação de riscos, de forma a seja incumbido de com eles arcar

8 Paulo Modesto, Reforma do Estado, Formas de Prestação de Serviços ao Público e Parcerias Público-Privadas: Demarcando as Fronteiras dos Conceitos de Serviço Público, Serviços de Relevancia Pública e Serviços de Exploraçāo Económica para as Parcerias Público-Privadas, in Parcerias Público-Privadas (org. Carlos Ari Sundfeld), Editora Malheiros, 2005, p. 483.

9 Marcos Barbosa Pinto, A Função Económica das PPPs, mimeo., gentilmente cedido pelo autor, p. 12. 
o parceiro que puder fazê-lo com os menores custos. De toda forma, qualquer que seja a alocação de riscos estabelecida no edital, a proposta do parceiro privado sempre poderá levá-la em conta em termos de preço, o que afasta possíveis alegações de onerosidade excessiva e consequiente violação do art. 37, inciso XXI, da Constituição.

\section{Aplicabilidade da Lei no 11.079/2004 a Estados, Distrito Federal e Municípios: a questão das normás gerais.}

A Lei $\mathrm{n}^{\circ} 11.079 / 2004$, em seu art. $1^{\circ}$, caput, proclama instituir "normas gerais para licitação e contratação de parceria público-privada no âmbito dos Poderes da União, dos Estados, do Distrito Federal e dos Municípios." E o faz em exercício da competência legislativa estabelecìda ṇo aıt. 22, inciso XXVII, da Constituição da República, que confere privativamente à União competência para dispor sobre "normas gerais de licitação e contratação, em todas as modalidades, para as administrações públicas diretas, autárquicas e fundacionnais da União, Estados, Distrito Federal e Municípios, obedecido o disposto no art. 37, XXI, e para as empresas públicas e sociedades de economia mista, nos termos do art. $173, \S 1^{\circ}$, III".

Pois bem. Tal não significa, entretanto, que todas as normas da Lei $\mathbf{n}^{\circ}$ 11.079/2004 exibam o conteúdo de norma geral. Aliás, o próprio legislador federal o reconhece ao destacar em capítulo próprio (Capítulo VI) dispositivos só aplicáveis à União Federal (arts. 14 a 22). O probléma é tal técnica legislativa conduz à equivocada presunção de que todas as demais normas da Lei seriam gerais, aplicáveis, assim, obrigatoriamente, a Estados, Dis:rito Federal e Municípios. Assim não me parece.

Vale lembrar, neste passo, o importante precedente consubstanciado na ADIN $\mathrm{n}^{\circ}$ 927-RS ${ }^{10}$, em cujo julgamento o Supremo Tribunal Federal, realizando uma operação de interpretação conforme à Constituição, entendeu que os dispositivos do art. 17, I, “b" e II, "b", I, “c" e parágrafo único, da Lei n 8.666/93 tinham aplicação apenas no âmbito da União Federal, por não exibirem o conteúdo de autênticas normas gerais. Embora mantido intacto o texto dos dispositivos impugnados, sua aplicabilidade aos demais entes foi afastada pelo STF, numa declaração parcial de inconstitucionalidade sem redução de texto.

O mesmíssimo raciocínio é aplicável à Lei n $11.079 / 2004$. É dizer: somente as normas contempladas no texto da aludida Lei que possam ser qualificadas como gerais serão de observância compulsória para os entes federativos menores. Assim, há que se perquirir, caso a caso, quais dentre as normas da Lei $n^{\circ} 11.079 / 2004$ descem de tal forma a minúcias ou detalhes, exaurindo o seu âmbito de normatividade, a ponto de perderem o status de norma geral.

$\mathrm{O}$ exemplo mais eloquiente de norma de conteúdo específico da Lei $\mathrm{n}^{\circ}$ 11.079/20G4, aplicável, como tal, somente aos contratos celebrados pela Administração Pública federal, é o art. $2^{\circ}, \S 4^{\circ}$, inciso I, que veda a celebração de contratos 
de parceria público-privada cujo valor seja inferior a $\mathrm{R} \$ 20.000,00$ (vinte milhões de reais). Embora compreendendo as razões que levaram o legislador a criar tal vedação - destinada a evitar o mau uso do regime das PPPs para contratos ordinários, de pequena monta - não se me afigura correto limitar o uso do instrumento por Estados, Municípios e DF pelo mesmo patamar.

Com efeito, a ordem de grandeza dos projetos e empreendimentos levados a efeito no âmbito federal é consideravelmente maior que a da maioria dos demais entes federativos. Assim, embora isso possa parecer uma porta aberta a abusos, entendo que cada ente federativo deve fixar seus próprios limites mínimos, compatíveis com a sua realidade sócio-econômica, mas sem descurar do fato de que as PPPs se destinam a situações excepcionais e que requeiram investimentos iniciais vultosos do parceiro privado.

De todo modo, caso haja abusos da parte de legisladores estaduais e locais, será sempre possível invocar o argumento do desvio de poder legislativo, configurado pelo uso de contratos de longo prazo e assegurados por garantias especiais para as mesmas situações acudidas por contratos de concessão comum, de simples prestação de serviços ou de obra pública.

IV. As garantias especiais das PPPs: exigência de lei complementar e problemas relativos ao fundo garantidor.

Uma das características peculiares dos contratos de PPP é o reforço das suas garantias em relação à generalidade dos contratos celebrados pela Administração Pública. A razão de ser de tal característica é de fácil compreensão: ao contrário dos demais contratos administrativos, as PPPs (i) exigem investimentos iniciais vultosos dos particulares, (ii) propõem sua amortização em longo prazo e (iii) no caso das concessões patrocinadas e das concessões administrativas de serviços públicos, não oferecem um objeto suficientemente atrativo para justificar per se os riscos assumidos pelos investidores privados.

A lógica econômica das garantias especiais das PPPs é a de proporcionar, aos parceiros privados, a possibilidade de obtenção de financiamentos no mercado em condições mais favoráveis, por conta da redução de riscos que elas oferecem. A garantia reforçada é a contrapartida das maiores exigências feitas ao parceiro privado, em contratos de PPP.

Nesta toada, prevê o art. $8^{\circ}$ da Lei $n^{\circ} 11.079 / 2004$ :

"Art. $8^{\circ}$ As obrigações pecuniárias contraídas pela Administração Pública em contrato de parceria público-privada poderão ser garantidas mediante:

$I$ - vinculação de receitas, observado o disposto no inciso IV do art. 167 da Constituição Federal;

II - instituição ou utilização de fundos especiais previstos em lei;

III - contratação de seguro-garantia com as companhias seguradoras que não sejam controladas pelo Poder Público; 
IV - garantia prestada por organismos internacionais ou instituiçōes financeiras que não sejam controladas pelo Poder Público;

$V$ - garantias prestadas por fundo garantidor ou empresa estatal criada para essa finalidade;

VI - outros mecanismos admitidos em lei."

A Constituição da República, a seu turno, assim dispõe em seu art. 163 (na redação introduzida pela $\mathrm{EC} \mathrm{n}^{\circ} 40 / 2003$ ):

"Art. 163. Lei Complementar disporá sobre:

I- finanças públicas;

II - dívida pública externa e interna, incluída a das autarquias, fundações e demais entidades controladas pelo Poder Público;

III - concessão de garantias pelas entidades públicas;

IV - emissão e resgate de títulos da dívida pública;

$V$ - fiscalização financeira da administração pública direta e indireta;

VI - operações de câmbio realizadas por órgãos e entidades da União, dos Estados, do Distrito Federal e dos Municípios;

VII - compatibilização das funções das instituições oficiais de crédito da União, resguardadas as características e condições operacionais plenas das voltadas ao desenvolvimento regional."

Em uma primeira leitura, o vício de inconstitucionalidade formal parece evidente. Deveras, sendo a Lei $n^{\circ} 11.079 / 2004$ uma lei ordinária, a exigência do art. 163, caput, e III, da Carta Política teria sido desatendida.

Há, no entanto, duas interpretações alternativas que poderiam salvar o art. $8^{\circ}$ da Lei $n^{\circ} 11.079 / 2004$. A primeira, aquela que sustenta ter a Lei $n^{\circ} 11.079 / 2004$ apenas regulamentado a Lei Complementar $n^{\circ} 101 / 200$ (Lei de Responsabilidade Fiscal), com o que estaria satisfeita a exigência constitucional. E a segunda, aquela segundo a qual o art. $8^{\circ}$ não trata da concessão de garantias por entidades públicas (referidas no caput do art. 163 da Constituição), mas sim por uma entidade privada, que é o Fundo Garantidor das Parcerias Público-Privadas (FGP).

Seja como for, o simples existência de uma suspeita de inconstitucionalidade já pode representar um elemento problemático de risco e insegurança para os investidores privados. Assim, é recomendável o encaminhamento de um projeto de lei complementar ao Congresso que venha a espancar dúvidas acerca da firmeza das garantias oferecidas pelos parceiros públicos em contratos de PPP.

De outra banda, estabelece o art. 18 da Lei $n^{\circ} 11.079 / 2004$ :

“Art. 18. As garantias do FGP serão prestadas proporcionalmente ao valor da participação de cada cotista, sendo vedada a concessão de garantia cujo valor presente líquido, somado ao das garantias anteriormente prestadas e demais obrigações, supere o ativo total do FGP. 
$\S 1^{o}$ A garantia será prestada na forma aprovada pela assembléia dos cotistas, nas seguintes modalidades:

I - fiança, sem beneficio de ordem para o fiador;

II - penhor de bens moveis ou de direitos integrantes do patrimônio do FGP, sem transferência da posse da coisa empenhada antes da execução da garantia;

III - hipoteca de bens imóveis do patrimônio do FGP;

$I V$ - alienação fiduciária, permanecendo a posse direta dos bens com o FGP ou com agente fiduciário por ele contratado antes da execução da garantia;

$V$ - outros contratos que produzam efeito de garantia, desde que não transfiram a titularidade ou posse direta dos bens ao parceiro privado antes da execução da garantia;

$V I$ - garantia, real ou pessoal, vinculada a um patrimônio de afetação constituído em decorrência da separação de bens e direitos pertencentes ao FGP.

$\S 2^{\circ} O$ FGP poderá prestar contra-garantias a seguradoras, instituições financeiras e organismos internacionais que garantirem o cumprimento das obrigações pecuniárias dos cotistas em contratos de parceria público-privadas.

§ $3^{\circ}$ A quitação pelo parceiro público de cada parcela de débito garantido pelo FGP importará exoneração proporcional da garantia.

$\$ 4^{\circ}$ No caso de crédito líquido e certo, constante de título exigível aceito $e$ não pago pelo parceiro público, a garantia poderá ser acionada pelo parceiro privado a partir do 45 (quadragésimo quinto) dia do seu vencimento.

$\S 50$ parceiro privado poderá acionar a garantia relativa a débitos constantes de faturas emitidas e ainda não aceitas pelo parceiro público, desde que, transcorridos mais de 90 (noventa) dias de seu vencimento, não tenha havido sua rejeição expressa por ato motivado.

$\S 6^{\circ}$ A quitação de débito pelo FGP importará sua subrogação nos direitos do parceiro privado.

\$ $7^{\circ}$ Em caso de inadimplemento, os bens e direitos do Fundo poderão ser objeto de constrição judicial e alienação para satisfazer as obrigações garantidas."

O óbice de natureza constitucional que tem sido oposto ao mecanismo do fundo garantidor tem por fundamento o art. 100 da Constituição, que institui o sistema de precatórios judiciais como forma de execução das dívidas do Poder Público e impõe a sua liquidação na ordem cronológica da sua apresentação. A execução direta de 
bens e direitos do fundo garantidor - alega-se - estaria fraudando o regime constitucional dos precatórios.

Aqui não se vislumbra qualquer vício. A uma, porque seria legítimo ao Poder Público desafetar determinado bem imóvel de seu patrimônio e dá-lo em garantia de um contrato. A desafetação do bem importa a possibilidade de disposição do bem, o que se pode fazer mediante as formas contratuais admitidas pelo direito. A constituição de uma hipoteca, por exemplo, seria uma forma válida de garantir um contrato de que o Poder Público fosse parte.

A duas, porque a fórmula da constituição de uma entidade de direito privado para funcionar como fundo garantidor é absolutamente legítima e respaldada pelo art. $173, \S 1^{\circ}$, inciso II, da Carta da República. Nada impede, de fato, que o Poder Público constitua uma empresa pública ou uma sociedade de economia mista (ou uma subsidiária dessas entidades) cujo objeto social seja o de garantir determinados projetos, concebidos no formato de PPP. Trata-se de um aspecto da atividade de fomento, que pode ser desempenhada por pessoas estatais de direito privado. Ora, segundo o art. 173, $\S 1^{\circ}$, inciso III, da Constituição, empresas públicas, sociedades de economia mista e suas subsidiárias sujeitam-se ao "regime jurídico próprio das empresas privadas, inclusive quanto aos direitos e obrigações civis, comerciais, trabalhistas e tributários."

Veja-se, então: se é legítima a constituição de uma pessoa estatal de direito privado com o objeto específico de dar garantias a projetos especiais sob a forma de PPP; se não há qualquer dúvida acerca da sujeição dessas entidades ao regime de execução e acionamento de garantias próprio das empresas privadas; impõe-se reconhecer como válido o expediente de constituição de um fundo privado para lastrear os contratos de PPP.

O que há de esdrúxulo na Lei $n^{\circ} 11.079 / 2004$ é o fato de não haver menção expressa ao tipo de entidade sob cuja forma seria constituído o fundo garantidor. Embora o art. $16, \S 1^{\circ}$ afirme ter ele natureza privada e patrimônio próprio, distinto daquele de seus cotistas, além de direitos e obrigações próprios, não há na Lei a definição sobre sua forma jurídica. Ora, a falta de definição legal transfere para a Administração Pública tal escolha. O que importa é que o fundo terá personalidade jurídica de direito privado, sujeitando-se, assim, ao regime próprio das empresas privadas, nos termos do art. $173, \S 1^{\circ}$, inciso III, da Constituição Federal.

\section{A arbitragem envolvendo a Administração Pública.}

Dispõe o art. 11, inciso III, da Lei $n^{\circ} 11.079 / 2004$ :

"Art. 11. O instrumento convocatório conterá minuta de contrato, indicará expressamente a submissão da licitação às normas desta Lei e observará, no que couber, os $\$ \$ 3^{\circ}$ e $4^{\circ}$ do art. 15, os arts. 18, 19 e 21 da Lei $n^{\circ} 8.987$. de 13 de fevereiro de 1995, podendo ainda prever: 
III - o emprego dos mecanismos privados de resolução de disputas, inclusive a arbitragem, a ser realizada no Brasil e em língua portuguesa, nos termos da Lei $n^{\circ}$ 9.307, de 23 de setembro de 1996, para dirimir conflitos decorrentes ou relacionados ao contrato."

Três são os óbices de índole constitucional comumente opostos à admissibilidade de cláusulas de arbitragem em contratos envolvendo a Administração Pública:

(i) o princípio da legalidade administrativa, óbice que poderia ser transposto mediante lei autorizativa expressa;

(ii) o princípio da indisponibilidade do interesse público, por isto que a arbitragem se prestaria apenas à solução de conflitos em torno de direitos disponíveis;

(iii) o princípio da inafastabilidade do controle jurisdicional, que impediria o caráter definitivo da sentença arbitral.

Nenhum deles se me afigura procedente. Antes ao contrário. Confira-se por quê.

Em primeiro lugar, a ausência de uma autorização legal explícita e específica não pode ser considerada per se como óbice à pactuação da cláusula compromissória em contratos da Administração. Tal exigência parte da premissa - equivocada de que a cláusula de arbitragem constitui um ato de disposição da Administração Pública, o que é equivocado.

A autorização legal (geral e orçamentária) para a realização de despesas pela Administração, mediante celebração de contratos com particulares, importa, $a$ fortiori, a autorização para que o administrador faça uso de todos os meios negociais disponíveis para a melhor consecução dos interesses da coletividade. Assim, v.g., pode a Administração Pública proceder ao acertamento direto de seus conflitos com os particulares, o que não ofende à legalidade. Por igual razão, pode a Administração pactuar a realização de procedimento arbitral, como o meio mais eficiente de solução de suas controvérsias com particulares. Trata-se de um poder implícito ao dever de bem administrar o patrimônio público e promover o interesse público aquele de obrigar-se à solução arbitral de conflitos.

Por outro lado, já foi há muito abandonada a idéia do princípio da legalidade administrativa como vinculação positiva à lei. Trata-se de um dogma, repetido de geração a geração, a noção de que toda atividade administrativa deve estar prévia e inteiramente prevista na lei. Há inúmeros campos em que, como se sabe, se reconhece à Administração uma série de poderes implícitos ao dever de bem administrar. A pactuação da cláusula compromissória é um dentre eles. A execução de tarefas públicas, mediante celebração de contratos com particulares, pressupõe o reconhecimento de um conjunto de poderes à Administração, como condição para a otimização do dispêndio de recursos e alcance dos fins perseguidos. Em uma palavra: o poder de pactuar arbitragem é implícito ao poder de contratar, restando atendida a 
legalidade quando a solução arbitral se afigura, a juízo do administrador, como aquela que realiza, da forma mais eficiente, o dever de bem administrar.

Nada obstante, tal questão sequer se coloca em relação às PPPs, diante da autorização expressa constante do art. 11, inciso III, da Lei $n^{\circ} 11.079 / 2004$. Exigir mais que isso - como, v.g., autorização legal caso a caso - seria um despautério, absurda violação do princípio constitucional da separação de poderes.

No que se refere ao princípio da indisponibilidade do interesse público, cumpre relembrar a lição do hoje Ministro Eros Roberto Grau, já antes vislumbrada, no sentido de que "não há qualquer correlação entre disponibilidade ou indisponibilidade de direitos patrimoniais e disponibilidade ou indisponibilidade do interesse público" ". Assim, à disponibilidade dos direitos patrimoniais envolvidos em um contrato administrativo corresponde um poder da Administração de convencionar a cláusula de arbitragem, sem que isso importe disposição do interesse público. ${ }^{12}$

Ademais, permito-me repetir que a pactuação da cláusula compromissória não se caracteriza como típico ato de disposição. Ao contrário, em muitos casos, a arbitragem poderá se apresentar como a melhor forma de resguardar o patrimônio público (interesse público secundário) e promover o interesse público (interesse público primário).

Do ponto de vista estritamente patrimonial, a arbitragem poderá ser, em muitos casos, a mais vantajosa para a Administração do que a solução judicial. Imagine-se, por exemplo, um contrato rescindido por culpa do parceiro privado, em que haja uma verba indenizatória devida à Administração. A maior celeridade do procedimento arbitral virá em favor do Poder Público. Em uma palavra: nada garante que a solução judicial seja a mais favorável ao patrimônio público. De outra parte, seria imoral - e, portanto, inconstitucional - imaginar que a Administração Pública devedora contumaz - possa preferir a solução judicial à arbitral por ser a primeira a mais morosa.

Já sob o prisma do interesse geral (interesse público primário), o grau de benefício gerado para a coletividade por contratos administrativos menos onerosos (por força da maior garantia ensejada pela arbitragem) deve ser ponderado com eventuais riscos decorrentes da não submissão dos litígios decorrentes de tais contratos da apreciação do Poder Judiciário. Em um juízo de proporcionalidade entre benefícios (custos mais baixos em contratos administrativos) e riscos (eventuais e suscetíveis de correção pontual em casos de vícios formais ou fraude, nos casos previstos no art. 32 da Lei $n^{\circ} 9.307 / 96$ ), a balança do custo-benefício me parece claramente pender em favor da convenção da cláusula compromissória.

Ademais, já tive oportunidade de consignar em outro estudo ${ }^{13}$ que a relação do interesse público com interesses privados não obedece a um esquema binário (inte-

11 Eros Roberto Grau, Arbitragem e Contrato Administrativo, Revista Trimestral de Direito Público - RTDP 32/20.

12 No mesmo sentido, v. Caio Tácito, Arbitragem nos Litigios Administrativos, Revista de Direito Administrativo - RDA 210/111-115.

13 Gustavo Binenbojm, Da Supremacia do Interesse Público ao Dever de Proporcionalidade: 
resse público versus interesses privados). Ao contrário, tratando-se de interesses privados assegurados pela Constituição como direitos fundamentais, sua preservação e promoção é de ser havida como meio de realização do próprio interesse público. Com efeito, a noção moderna de interesse público não é obtida por oposição aos interesses particulares, mas mediante juízos ponderativos que permitam a concretização de interesses individuais e metas coletivas, na maior extensão possível. Assim, pode-se afirmar que a maior celeridade, a maior especialização e o maior grau de imparcialidade (sobretudo em contratos que envolvam parceiros privados estrangeiros) propiciados pela arbitragem são elementos que, em um juízo de ponderação, conduzem à conclusão de que a solução arbitral, em determinadas circunstâncias, é a que realiza pontualmente o melhor interesse público.

Por derradeiro, e já tendo em conta tudo que antes se expôs, não há que se falar em violação do princípio da inafastabilidade da jurisdição. Resolvida que foi, pelo Supremo Tribunal Federal, a questão da constitucionalidade do procedimento arbitral $^{14}$, e assentado que a opção pela cláusula de arbitragem é uma decorrência da disponibilidade dos recursos envolvidos no contrato administrativo, qualquer alegação de violação da garantia constitucional da inafastabilidade da jurisdição perde sentido.

De fato, segundo entendimento do STF, a renúncia à tutela jurisdicional é válida quando em jogo interesses disponíveis. Ora, permitida a disponibilidade dos recursos públicos mediante contratação administrativa, segue daí que a Administração poderá também convencionar a forma pela qual os litígios decorrentes do contrato serão dirimidos. $\mathrm{O}$ acessório (cláusula compromissória) segue a sorte do principal (disponibilidade dos interesses envolvidos no contrato).

De todo modo, a tutela jurisdicional poderá ser invocada nos casos admitidos pela Lei $n^{\circ} 9.307 / 96$, nomeadamente em seus arts. 32 e 33, resguardando-se, em medida razoável e proporcional, os interesses patrimoniais do Estado contra eventuais desvios cometidos no curso da arbitragem.

um Novo Paradigma para o Direito Administrativo, Revista de Direito Administrativo - RDA 239/1-31.

14 Sentença Estrangeira (SE) n 5.206-7, rel. Min. Sepúlveda Pertence, j. 12.12.2001. 


\section{Direito Internacional Privado Volume I - A Familia no Direito Internacional Privado Tomo I-Casamento e Divórcio

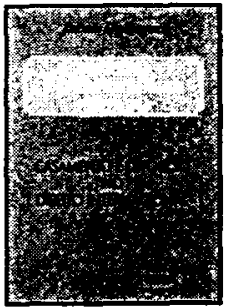 \\ Jacob Dolinger \\ Ret. 0140 \\ Encadernado \\ 420 págs. \\ Form. $16 \times 23$ \\ 1997 \\ ISBN 85-7147-049-9}

0 Direito Internacional Privado acompanha os grandes ramos do direito nas suas dimensões internacionais, que se materializam sempre que as relações humanas têm conexão com mais de um sistema jurídico, nacional ou pessoal. Este volume é dedicado às questões referentes ao matrimônio - casamento e divórcio - na sua dimensão internacional, enfrentando toda a multiplicidade de problemas que se impõem nesta seara.

\section{Direito Internacional Privado Volume I - A Familla no Direito Internacional Privado Tomo II - A Criança no Direito Internacional}

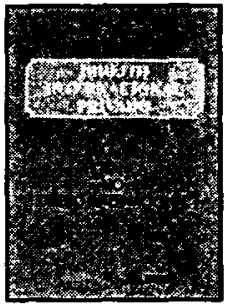
Jacob Dolinger
Rel. 0462
Encadernado
567 págs.
Form. 16×23
2003 / Prelo
ISBN 85-7147-385-4

Este não é um estudo centrado apenas nas relações entre pais e filhos, ele abrange, de forma mais ampla, os direitos da criança, sua posição no direito internacional, no seu sentido total. Esta perspectiva nova não se divorcia muito do prisma clássico, pois em determinadas circunstâncias ocorre o encontro da solução do conflito das leis com a proteção à criança.
Direito Internacional Privado Arbitragem Comercial Internacional

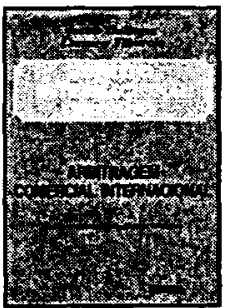
Jacob Dolinger / Carmem Tiburcio

Ret. 0468

Encadernado 1078 págs. 2003

Form. $16 \times 23$

ISBN: $85-7147-397-8$

É dividido em três partes: doutrina, jurisprudência comparada e comentada e legislação. Parte l: questōes fundamentais, antecedentes históricos e desenvolvimento da arbitragem no Brasil. Parte II: 19 temas polêmicos, que têm sido debatidos perante tribunais arbitrais, tribunais estatais estrangeiros e tribunais brasileiros. Parte III: Iegislaçāo brasileira sobre a matéria, atual e pretérita, legislação de arbitragem de países com os quais o Brasił mantém relaçōes comerciais.

\section{Direito Internacional Privado Parte Geral}

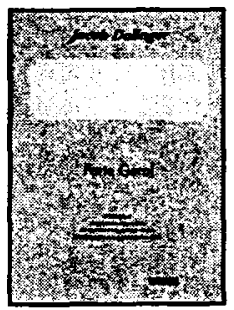

\section{Jacob Dolinger \\ Ref. 0056 \\ Encadernado \\ 552 págs. \\ Form. $16 \times 23$ \\ $2003 / 7^{2} \mathrm{ed}$. \\ ISBN 85-7147-366-8}

As múltiplas relações privadas internacionais, no campo do direito civil, comercial e processual, relacionadas com sistemas jurídicos diversos e muitas vezes divergentes, são disciplinadas pelo sobredireito espacial, que formula um complexo de regras e princípios para orientar 0 aplicador da lei na escolha do sistema jurídico adequado para determinada situação ou relação jurítica. A presente obra concentra-se na parte geral da ciência. 